\title{
Where are the Adults? First Results of a Study on C. Mydas Foraging in New Caledonia
} \author{
and Colin J Limpus ${ }^{5}$ \\ ${ }^{1}$ Laboratory of Marine Biology and Ecology, Aquarium des Lagons, New Caledonia \\ ${ }^{2}$ EA4243 LIVE, Universié de la Nouvelle-Calédonie, New Caledonia \\ ${ }^{3}$ Griffith Centre for Coastal Management, Griffith University Gold Coast campus, Australia \\ ${ }^{4}$ Ocean and Coast Research, Main Beach, Australia
}

Tyffen C Read ${ }^{1 *}$, Laurent Wantiez ${ }^{2}$, Jonathan M Werry ${ }^{3,4}$, Richard Farman ${ }^{1}$, Olivier Chateau ${ }^{1}$, Florent Keller ${ }^{1}$

${ }^{5}$ Department of Environment and Heritage Protection, Queensland Government, Australia

Submission: November 19, 2019; Published: January 06, 2019

Corresponding author: Tyffen C Read, Laboratory of Marine Biology and Ecology, Aquarium des Lagons, Noumea, New Caledonia

Abstract

A total of 183 C. mydas individuals were caught foraging in the Grand Lagon Sud (GLS) of New Caledonia. This area was added to the World Heritage list in 2008 but turtles are still being hunted for traditional use in that area. C. mydas were captured in three different areas by the rodeo method with the knowledge of the traditional landowners, so females as well as males and juveniles could be sampled.. All individuals were tagged and measured before being released where they were caught. No adults were captured and only 5 sub-adults were encountered. No significant difference in the size Curved Carapace Length (CCL) was found between the individuals caught during nesting season when compared to the ones caught outside nesting season but adults were captured during the same period for traditional use. There results show that recruitment is happening for C. mydas in New Caledonia but also raise concerns about the number of adults in the area.

\section{Introduction}

Chelonia mydas (green turtles) are an endangered species (IUCN, 2010) found in tropical and sub-tropical waters around the world [1]. The number of large individuals of $C$. mydas have declined significantly in many countries of the Pacific Ocean due to overharvesting [2]. This species has a very complex life cycle: C. mydas are known to nest on sandy beaches and hatchlings disperse to pelagic waters for a period that varies between 5-6 years [3]. They then recruit to neritic waters, usually at a size $40 \mathrm{~cm}$ curved carapace length (CCL) and become resident to their foraging area [2]. They also shift their diet from omnivorous to mainly herbivorous [4]. When they reach sexual maturity, aged between 25 and 50 years old depending on food availability [5], they start to migrate (once every 2 to 5 years) back to the beach where they were born in order to reproduce [6].

These migrations last for months at the time, depending on the distance between the nesting and foraging sites but the individuals come back to their foraging site $[1,7,8]$. And the life cycle also has a geographical complexity: studies have shown that C. mydas can migrate $100-1000$ 's of km's to reach their nesting beach and thus can cross international waters $[9,10]$. This has implication for stock management, and the need to identify the different populations and to have an extensive knowledge of the different stages (pelagic, oceanic and neritic) for each population is critical [11-13]. Foraging areas are known to be "mixed stocks" [14], meaning that not all individuals found in one foraging area belong to the same management unit and belong to different genetic stocks. The genetic diversity of $C$. mydas in the South Pacific has been studied and individuals found in New Caledonian waters belong primarily from the New Caledonian stock (D'Entrecasteaux reefs) and also from at least four different stocks : $1=$ southern GBR, 2= Coral Sea; 3= northern GBR and 4= Gulf of Carpentaria (Figure 1) [14].

C. mydas are commonly seen in New Caledonia, they are protected in 2 of the provinces (South and North Provinces) out of 3 (the other one being the Island Province) but they have been used as a main source of protein for hundreds of decades by Melanesians but also by sailors that were on exploration trips or were stranded in the area [15]. Sea turtles are protected in 
New Caledonia, but permits are given for tribal ceremonies such as the yam celebration or weddings of chiefs. The present paper relates the first results of a study on the population structure of the foraging population of $C$. mydas in the south of New Caledonia. It is thought that New Caledonia is an important area in the life cycle of green turtles in the South Pacific, but no data is available to support this. By sampling a large foraging area and obtaining population dynamics and key demographic parameters, it will give us an insight on the ecology of the individuals found in New Caledonia and help in the conservation steps of that highly migratory species.

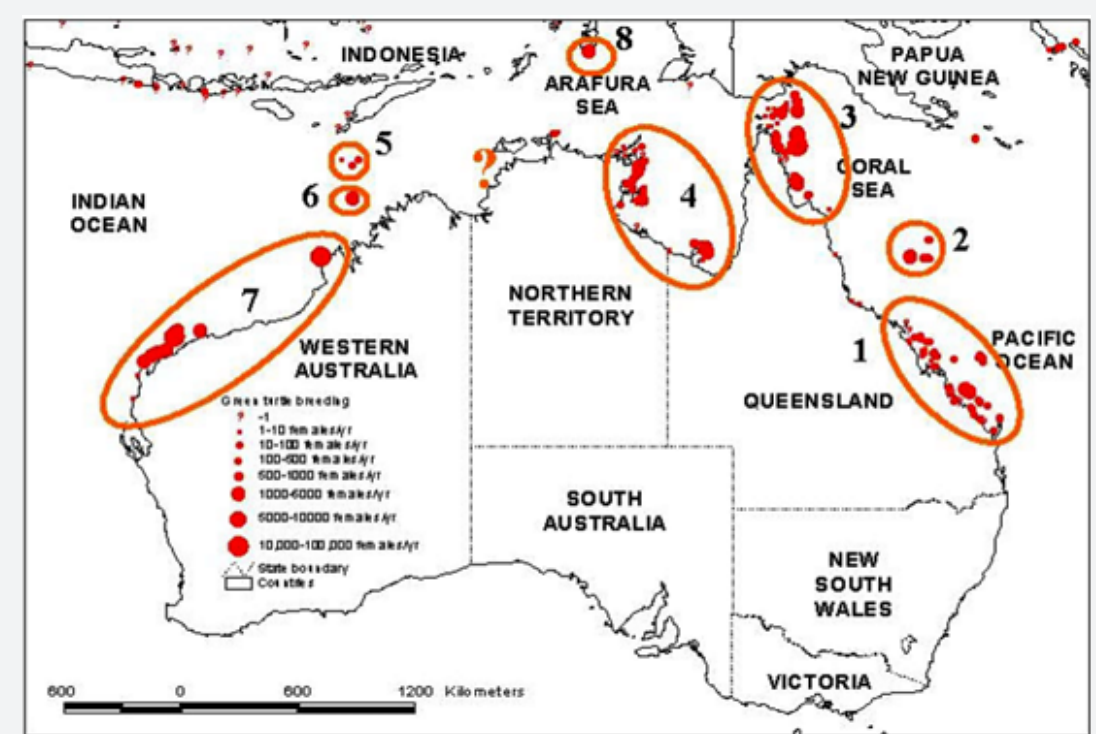

Figure 1: The different genetic stocks of $C$. mydas found in Australia.

\section{Methods}

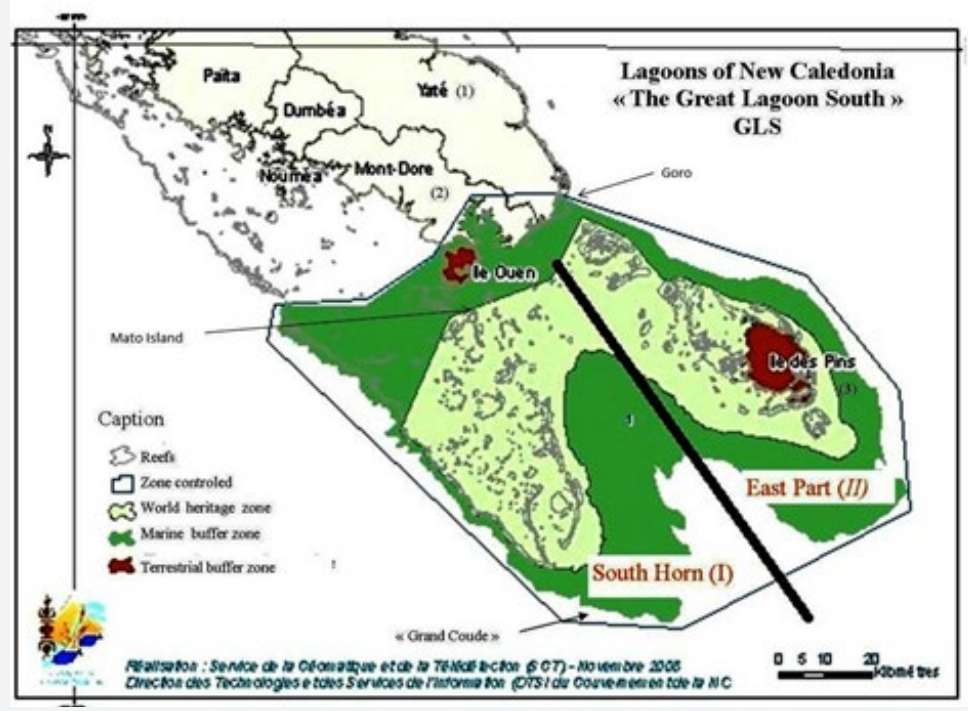

Figure 2: Map of the GLS with the different world heritage zonations.

This study was conducted in the Grand Lagon Sud (GLS)

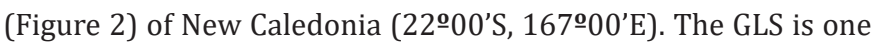
of six areas of New Caledonia added to the World Heritage List in 2008 for its reef diversity and associated ecosystems (UNESCO). In addition to its large reef diversity, the GLS was chosen to become a world heritage area for its rich marine biodiversity including numerous emblematic species, such as turtles, whales, dugongs, nautiluses, seabirds, sea snakes, dolphins, mink whales and large sharks. Its geographical location means that the GLS provides a unique habitat for species adapted to strong currents and cooler waters. GLS has an area of 314500 ha, a marine buffer zone of 313100 ha and a land buffer zone of 15800 ha. The buffers are 
not directly part of the world heritage zone but are an additional guarantee of the site's preservation.

The area is composed of two zones, which are morphologically distinct: East part (I) and the South Horn (II) (Figure 2). The first zone is characterized by its reef diversity, the presence of an island (Isle of Pins) with fringing reefs and the only sanctuary of the GLS. The South Horn is the least diverse habitat; it has an external barrier reef that has 10 channels [16]. Both zones (I and II) are known for their extensive grass and algal communities and especially in the "Grand Coude" (tip of the South Horn) (Figure 2). Isle of Pines is the only known nesting site for $C$. mydas in the GLS and was only in the order of 1 to 10 females a year in 1996 (Limpus, pers. comm.) so the population found foraging in the GLS originates from elsewhere. Three areas were specifically sampled after pilot studies done in the area and using tribal knowledge (Figure 2):

- $\quad$ Mato and Uo Islands

- Goro

- $\quad$ Ouen Island

Table 1: List of the different field trips done in order to sample C. mydas in the GLS of New Caledonia.

\begin{tabular}{|c|c|c|}
\hline Site & Date & Number of C. mydas caught \\
\hline Goro & $6 / 8 / 2012$ & 21 \\
\hline Ile Ouen & $20 / 08 / 2012$ & 13 \\
\hline Goro & $23 / 08 / 2012$ & 33 \\
\hline Mato/Uo & $03-07 / 09 / 2012$ & 54 \\
\hline Goro & $27 / 09 / 2012$ & 2 \\
\hline Goro & $13 / 12 / 2012$ & 11 \\
\hline Uo & $08-09 / 01 / 2013$ & 5 \\
\hline Ile Ouen & $22 / 01 / 2013$ & 44 \\
\hline
\end{tabular}

The closest population (geographically) of studied C. mydas is the one found in eastern Australia. Given that the breeding season for C. mydas in eastern Australia extends from October to April, it is reasonable to hypothesise that the breeding season for New Caledonian C. mydas is within the same period. The timing of the first field sampling periods was chosen so that all $C$. mydas associated with a foraging area were available for capture, i.e. all turtles preparing to breed for the year are in their pre-migratory phase, thus were in their foraging area. Seasonal patterns were investigated in this study as all sampling sites were visited at least once per season, knowing that the seasons used are nesting season (October to May) and outside nesting season (Jun-September) (Table 1).
Turtles were captured by the turtle rodeo method [18]. No tribes live on Mato and Uo Islands, so a crew and boats were landed by the Aquarium Des Lagons. On the other hand, at Goro and Ile Ouen, people live and fish on a regular basis. Local people with their own boats were involved in the sampling campaigns. All individuals caught were tagged with a titanium tag [1], measured (CCL) and sexed when possible. The individuals captured were then divided into 3 categories depending on their size according to Limpus et al. [3] and Limpus and Chaloupka [2]: juveniles were between 20 and $65 \mathrm{~cm}$ curved carapace length (CCL), sub-adults between 65 and $90 \mathrm{~cm}$ CCL and finally adults were $90 \mathrm{~cm} \mathrm{CCL}$ and plus.

In 2013 and 2014, CCL was recorded and gonads interpretation were done on individuals hunted by tribes for traditional ceremonies. Photographs of the reproductive system were taken during the carving of the individuals. Gonads were scored by sex, maturity and breeding status using the methods of Limpus (1992) and Limpus and Limpus (2003) (Limpus 1992b) and Limpus et al. 2005.

Females were scored in four categories:

1. Pubescent immature (compact ovary, no scars and oval oviduct $\sim 10 \mathrm{~mm}$ diameter)

2. Preparing for breeding (ovary with enlarged vitellogenic follicles $>1 \mathrm{~cm}$ diameter)

3. Bred in the previous season (presence of healing corpora lutea ( $>3 \mathrm{~mm}$ diameter) and enlarged atretic follicles).

4. Bred in the season before last or up to 3 years ago (presence of corpora albicantia $\sim 3 \mathrm{~mm}$ diameter and white radiating connective tissue).

\section{Data analysis}

To test for differences in the individual's sizes between location and seasons, a mix model two-way ANOVA was done to assess the effect of the season and the area on the Curved Carapace Length (CCL) of the individuals caught during the different field trips. Assumptions for ANOVA were tested prior to the analyses: no significant deviation from normality [18] and variances not significantly different between treatments (Batlett test, $\mathrm{p}<$ $0.05)$. Data were transformed using $\log (x+1)$ to respect these assumptions. A posteriori Tukey HSD test was running to look for patterns or relationships between subgroups of the population in case of significant differences (ANOVA, $p<0.05$ ). The difference of sampling distribution between season and sites was tested using a Chi square test. All statistical analysis was performed using Stat graphics Software, and significance assumed if $\mathrm{P}<0.05$.

\section{Results}

182 green turtles were captured and measured within the GLS during the first year of the study. Their size ranged from 38 to 78.4 $\mathrm{cm} \mathrm{CCL} \mathrm{with} \mathrm{a} \mathrm{mean} \pm$ SD of $50.3 \pm 7.0 \mathrm{~cm}$ (Figure 3). The CCL 
of the individuals caught inside nesting season or outside nesting season were not significantly different (2-way Anova, $F=6.44$, $\mathrm{P}>0.1$ ) but a very significant difference was observed between areas ( 2-way Anova, F=14.89, $\mathrm{P}=0$ ). The post-hoc analysis showed that the areas of "Uo" and "Goro" both had smaller means in CCL than "Ile Ouen" (Tukey test, $\mathrm{P}<0.05$ ). The frequency at which the different CCL was caught were independent to the season $(\mathrm{P}>0.1)$ but was highly dependent to the area $\left(\chi^{2}, \mathrm{P}=0\right)$. Four sub-adults were caught at Ile Ouen, only one was caught at Goro and none in the Uo area.
A total of 15 females had their gonads examined during this study (Table 1). One female was preparing to bred in the next season, two had bred during the last season, but most had breed during seasons two or more years in the past $(n=8)$ and four were immature. All individuals examined were resident turtles of the GLS meaning that the C. mydas used for the traditional ceremonies are part of the mixed stock foraging in the study area. Thus from the genetic analysis [14] it can be hypothesised that a majority of the individuals belong to the d'Entrecasteaux genetic stock.

Figure 3: Distribution of the size of C. mydas $( \pm 7.0 \mathrm{~cm})$ captured at the different areas in the GLS, New Caledonia.

\section{Discussion}

In 2012, the department of environment (DENV, Province Sud) gave the authorisation for 41 turtles to be caught for traditional purposes and numbers are similar for 2013 and 2014 (mostly for the yam celebration and weddings). No significant difference in CCL was found between the nesting season and outside of the nesting season. This shows that the areas sampled are not important corridors for migrants which are sustained by a very low numbers of nesting females in the GLS during nesting season: last reported sighting in 1996 (Limpus, pers. Comm). No adults were captured during all the field trips within the area. The mean CCL shows a very young population that only recruited to the coastal areas in the last couple of years.

However, a significant difference was found when the CCL's were compared by area. This can be explained by the low numbers of sub-adults (SA) caught only one SA was found in Goro and 4 were captured in Ile Ouen. More captures in the different areas will validate or discredit the actual hypothesis that "Goro" and "Uo" support smaller individuals then "Ile Ouen". This does not change anything to the fact that no sexually active individuals were encountered at any of the sites.

The frequency at which C.mydas were caught was similar inside and outside nesting season but once again when compared per area, a difference was found due to unbalanced sampling. The catch-effort will be increased this year, and this will certainly adjust the results.
A study in US showed that two locations separated only by a couple of kilometers had very different size partitioning: adults and sub-adults were caught at one location, with straight carapace length (SCL) ranging from 69.3 to $108.5 \mathrm{~cm}$ compared to juveniles with SCL ranging from 27.0 to $59.3 \mathrm{~cm}$ ) in the second location [19].

Shoal water Bay, in Australia, was the location for a foraging ground study for C. mydas. During the 4-year period the study lasted, the ratio of juveniles was the highest found (with $37 \%$ ) but not far from sub-adults (32\%) and adults (31\%). The population in Shoal water bay seems to be homogeneous [20]. Another study done in Australia surveyed 4 different locations: Moreton Bay, Heron/ Wistari Reef, Clack Reef and then again Shoal water Bay. The individuals caught were only divided into 2 distinct categories, immature and adult. In Moreton Bay, 96\% of C. mydas captured were immature compared to $64 \%$ in Heron/Wistari Reef. At Clack Reef, $87 \%$ were immature and in Shoal water Bay 64\% percent were also immature, which correlates with the results found in the earlier study if we add the juveniles to the sub-adults [5]. This could mean that the new areas that will be sampled could possibly show clear partitioning in the size class of the C.mydas residing in the GLS of New Caledonia.

Recaptures were not analysed in this paper, as numbers are too low, but within the juveniles caught in "Goro", a small number $(n=15)$ of them can be categorised as new recruits. They are distinguishable by their white ventral surfaces and the carapace has sharp edges. One turtle (K90680) was recaptured in the same 
area at which it was initially tagged but 4 months later, the plastron was pale yellow and covered green algal growths. These changes were also seen in individuals in Shoalwater Bay [20] and was also recorded in loggerhead turtles [21]. The large number of juveniles (and new recruits) could mean that the population is hitting a spur in growth that could be explained by the changes in the legislation. For example, the South Province implemented its new protection law on sea turtles in 2006 ( $\left.\mathrm{N}^{\circ} 20-2006 / \mathrm{APS}\right)$, it states that fishing sea turtles and collecting eggs is no longer authorized and that permits will be given for specific tribal ceremonies.

From the tag recoveries made in New Caledonian waters, , individuals found foraging in New Caledonia belong to multiple breeding populations thus the management unit extends across the Coral Sea [14]. In Queensland, C. mydas is protected as a threatened species under the Nature Conservation Act 1992. This could mean that we could be witnessing the results from the conservation changes. Queensland government also allows aboriginal communities to kill sea turtles for traditional purposes but in 2012 an amendment was made in order to reduce the cruelty in the hunting and killing of turtles [22]. The areas sampled could be a nursery for the new recruits and juveniles.

\section{Conclusion}

For now, no seasonal patterns were found in the resident population of $C$. mydas foraging in the GLS of New Caledonia. No adults were found foraging in the sampling areas. More data should be collected in the area in order to understand the ecology and habitat use of this species and the role of New Caledonia within the South Pacific. New recruits are a positive sign for C. mydas in the area which is not the case for the other two species found foraging in New-Caledonia (Eretmochelys imbricata and Caretta caretta ) for which no juveniles were seen during the study. It should be noted that during this study, the natural reserve "Merlet" located within the Great Lagoon South could not be sampled and it can be hypothesized that large individuals can be found there.

\section{References}

1. Bowen B W, Meylan A B, Ross J P, Limpus C J, Balazs G H, et al. (1992) Global population structure and natural history of the green turtle (Chelonia mydas) in terms of matriarchal phylogeny. Evolution 46(4): 865-881.

2. Limpus C, Chaloupka M (1997) Nonparametric regression modelling of green sea turtle growth rates (southern Great Barrier Reef). Marine Ecology Progress Series 149: 23-34.

3. Limpus C J, Couper P J, Read M A (1994) The green turtle, Chelonia mydas, in Queensland: population structure in a warm temperate feeding area. Memoirs of the Queensland Museum. 35(1): 139-154.

4. Bjorndal K A (1997) Foraging ecology and nutrition of sea turtles. In: Musick PL L J A (ed.) The biology of sea turtles. CRC Press, London.

5. Chaloupka M, Limpus C, Miller J (2004) Green turtle somatic growth dynamics in a spatially disjunct Great Barrier Reef metapopulation. Coral Reefs 23: 325-335.
6. Carr A (1967) So Excellent a Fishe: A Natural History of Sea Turtles, Charles Scribner's Sons, New-York, USA.

7. Broderick A C, Coyne M S, Fuller W J, Glen F, Godley B J (2007) Fidelity and over-wintering of sea turtles. Proc Biol Sci 274(1617): 1533-1538.

8. Mortimer J A, Carr A (1987) Reproduction and migrations of the Ascension Island green turtle (Chelonia mydas). Copeia 1987(1): 103113.

9. Cheng I J (2000) Post-nesting migrations of green turtles (Chelonia mydas) at Wan-An Island, Penghu Archipelago, Taiwan. Marine Biology 137: 747-754

10. Luschi P, Papi F, Liew H C, Chan E H, Bonadonna F (1996) Long-distance migration and homing after displacement in the green turtle (Chelonia mydas): A satellite tracking study. Journal of Comparative Physiology a-Sensory Neural and Behavioral Physiology 178: 447-452.

11. Bowen B W, Bass A L, Soares L, Toonen R J (2005) Conservation implications of complex population structure: lessons from the loggerhead turtle (Caretta caretta). Mol Ecol 14(8): 2389-2402.

12. Arthur K E, Boyle M C, Limpus C J (2008) Ontogenetic changes in diet and habitat use in green sea turtle (Chelonia mydas) life history. Marine Ecology-Progress Series 362: 303-311.

13. Bolten A B (2003) Variation in sea turtle life history patterns: neritic vs. oceanic development stages. In: PL Lutz, J A M J W (Eds.) The biology of sea turtles. CRC Press, Washington D C, US.

14. Read TC, FitzSimmons NN, Wantiez L, Jensen MP, Keller F, et al. (2015) Mixed stock analysis of a resident green turtle, Chelonia mydas, population in New Caledonia links rookeries in the South Pacific. Wildlife Research 42(6): 488-499.

15. Lahanas P N, Bjorndal K A, Bolten A B, Encalada S E, Miyamoto M M et al. (1998) Genetic composition of a green turtle (Chelonia mydas) feeding ground population: evidence for multiple origins. Marine Biology 130: 345-352.

16. Pritchard P (1982) Marine turtles of the South Pacific. In: Biology and Conservation of Sea Turtles. Smithsonian Institution Press, Washington, US, Pp. 253-262.

17. Serge Andréfouët, Damaris Torres-Pulliza, M (collab) Dosdane, Christine Kranenburg (2004) Atlas récifs coralliens de NouvelleCalédonie, New Caledonia, IRD Nouméa.

18. Limpus C J, Reed P C (1985) The green turtle, Chelonia mydas, in Queensland: population structure in a coral reef feeding ground. In: Eds G C Grigg, R S A H E (eds.) The Biology of Australasian Frogs and Reptiles, Surrey Beatty and Sons, Sydney, Australia

19. Underwood A J (1996) Experiments in ecology: their logical design and interpretation using analysis of variance, Cambridge University Press.

20. Bresette M J, Witherington B E, Herren R M, Bagley D A, Gorham J C, et al. (2010) Size-class partitioning and herding in a foraging group of green turtles Chelonia mydas. Endangered Species Research 9: 105116.

21. Limpus C J, Limpus D J, Arthur K E, Parmenter C J (2005) Monitoring Green Turtle Population Dynamics in Shoalwater Bay: 2000-2004. In: Great Barrier Reef Marine Park Authority, Townsville, Australia

22. Limpus C J, Limpus D J (2003) The biology of the loggerhead turtle, Caretta caretta, in the southwest Pacific Ocean foraging areas. In Bolten E B W A (ed.) Biology and Conservation of Loggerhead Turtles. Smithsonian Institution Press, Washington, US.

23. Queensland Government, D O A, Fisheries And Forestry (2012) Amendments to protect dugongs and turtles. 
24. IUCN (2010) IUCN Red List of Threatened Species.

25. Limpus C J (1992) Estimation of tag loss in marine turtle research. Wildlife Research 19: 457-469.

26. Limpus C J (1997) Marine turtle population of the South East Asia and the Western Pacific Region: distribution and status. Proceedings of the
Workshop on Marine Turtle Research and Management in Indonesia. Wetlands International.

27. Limpus C J, Miller J D, Parmenter C J, Reimer D, Mclachlan N, et al (1992) Migration of green (Chelonia mydas) and loggerhead (Caretta caretta) turtles to and from eastern Australian rookeries. Wildlife Research 19: 347-358.

DOI: 10.19080/OFOAJ.2020.11.555815

\section{Your next submission with Juniper Publishers} will reach you the below assets

- Quality Editorial service

- Swift Peer Review

- Reprints availability

- E-prints Service

- Manuscript Podcast for convenient understanding

- Global attainment for your research

- Manuscript accessibility in different formats

( Pdf, E-pub, Full Text, Audio)

- Unceasing customer service

Track the below URL for one-step submission https://juniperpublishers.com/online-submission.php 